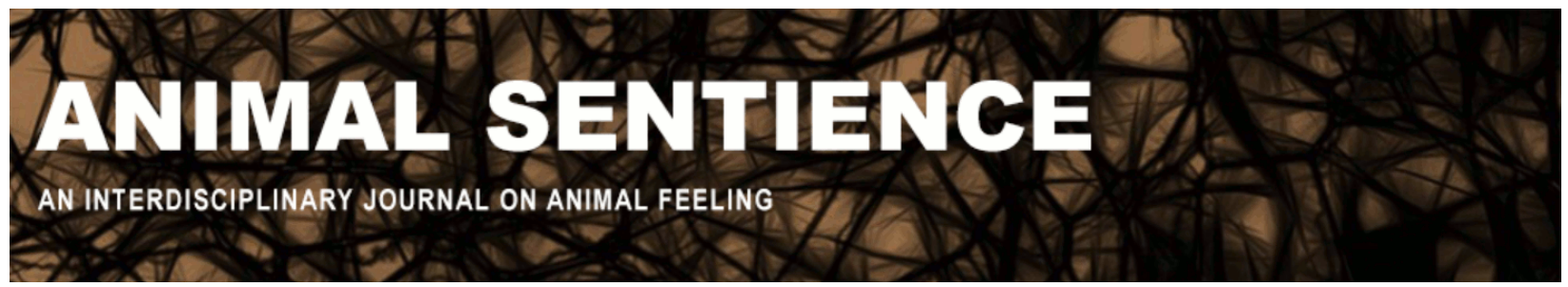

Washington, Haydn (2019) Justice for nature. Animal Sentience 27(2)

DOI: $10.51291 / 2377-7478.1529$

Date of submission: 2019-11-04

Date of acceptance: 2019-11-08

(c) (i)

This article has appeared in the journal Animal

Sentience, a peer-reviewed journal on animal

cognition and feeling. It has been made open access,

free for all, by WellBeing International and deposited

in the WBI Studies Repository. For more information,

please contact

wbisr-info@wellbeingintl.org.

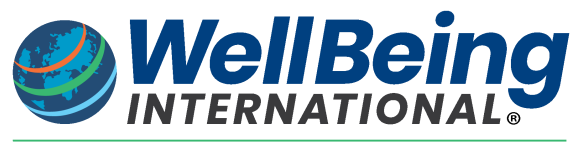

SOLUTIONS FOR PEOPLE, ANIMALS AND ENVIRONMENT 


\title{
Justice for nature
}

Commentary on Treves et al. on Just Preservation

\section{Haydn Washington}

PANGEA Research Centre, University of New South Wales, Australia

\begin{abstract}
Eight points are made in this commentary: (1) Ecocentrism is the preferable term. (2) Indigenous societies have long used a kinship ethics. (3) Earth jurisprudence and ecodemocracy should be considered. (4) Assumptions can be better defined. (5) Ethical pluralism is open to question. (6) The ethics of individuals vs. ecosystems needs further discussion. (7) Including justice for nature within social justice may be a serious mistake. (8) Trustees need to be ethically sophisticated.
\end{abstract}

Haydn Washington, adjunct lecturer at UNSW, has a forty-year history as an environmental scientist, writer and activist. He has worked in CSIRO, as Director of the Nature Conservation Council of NSW, Director of Sustainability in Local Government, and Co-Director of the NSW Chapter of the Center for the Advancement of a Steady State Economy. Website

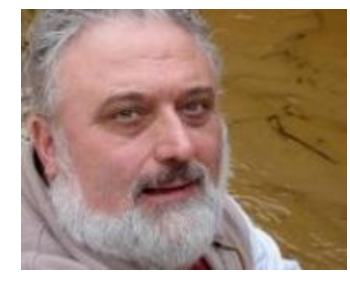

Congratulations to Treves et al. (2018/19) for their target article and thanks to Animal Sentience for inviting commentaries on this important issue. I completely agree with the target article's statement:

In sum, anything less than fairly balancing the well-being of humans and non-humans, now and into the future, would be anthropocentric and unjust.

The authors' redefinition of 'futurity' is also interesting. I see extensive commonality between their article and our paper 'Foregrounding ecojustice in conservation' (Washington et al. 2018). It is wonderful to see other academics promoting justice for the nonhuman! I believe our agreement far outweighs any differences. However, there are inevitably some things that merit a commentary. I list these in eight points:

1. Definitions. Treves et al. have a glossary but I find it somewhat confusing. They resurrect an old term 'geocentrism' as recognizing 'the intrinsic value of people, animals, and nature as individuals and social-ecological communities'. In contrast, Washington et al. (2017: p. 35) note:

Ecocentrism is the broadest term for worldviews that recognize intrinsic value in all lifeforms and ecosystems themselves, including their abiotic components. 
Washington et al. further note that ecocentrism goes beyond biocentrism (seeing value in all living things) by including environmental systems as wholes. It also goes beyond zoocentrism (seeing value in animals) in explicitly including plants and geodiversity. Ecocentrism and ecological ethics are the focus of Curry (2011) and The Ecological Citizen journal. Rolston (2012) uses the term 'Earth ethics' for the same topic. The target article, however, makes no mention of ecocentrism. Indeed, it is limited to zoocentrism (or at most biocentrism). Geodiversity is not seen as deserving of intrinsic value, but it should be (Washington 2018a). I understand that this is the journal Animal Sentience, but there seems to be some "botanodenial' operating in the target article: plants are never mentioned as deserving of ethical consideration. Moral standing should be given to all of biodiversity and geodiversity (Washington 2018b).

2. The target article says: 'we propose a fundamental re-imagining of what nature protection ought to mean and with it reintroduce the term preservation'. The idea of kinship with nature has very deep roots in indigenous societies - what Knudtson and Suzuki (1992) called a 'sacred ecology'. It is thus not so much a 're-imagining' that is needed as a rejuvenation of indigenous kinship ethics (Washington 2018b). Whether the term 'preservation' is more correct than 'conservation' is dubious. The terms were battled over in the US by John Muir (preservation) and Gifford Pinchot (conservation via 'wise use') in the early 1900s, but the rest of the world now uses the term 'conservation' to cover both ideas. Kopnina and Washington (2019) define conservation as: 'the protection or preservation of nonhuman nature'. Seeking to resurrect the term 'preservation' to replace conservation thus seems neither necessary nor useful.

3. Treves et al. argue for 'multi-species justice' (i.e., biocentrism) and the need to change jurisprudence, yet nowhere do they actually refer to (or support) the growing field of Earth jurisprudence (e.g., Cullinan 2014). The argument for preservation 'trustees' also has strong links to ecodemocracy (e.g., Gray and Curry 2019; www.ecodemocracy.net). The proposal seems to straddle the two fields, but each is worthy of greater definition and discussion.

4. Regarding ethics, I recommend Curry (2011) and his discussion of the 'Sole Value' assumption (strong anthropocentrism) and the 'Greater Value' assumption (soft anthropocentrism). Washington and Kopnina (2019) suggest a 'Nature First' assumption to replace both.

5. Treves et al. support a strong 'pluralistic approach' to ethics. However, pluralism has weakened the meaning of both sustainability (Washington 2015) and ecological economics (Spash 2012).

6. Individuals vs. ecosystems. Treves et al. criticize Washington et al. (2018) for 'cursory treatment of what individual nonhumans deserve from humans'. I cannot agree, but this does highlight the conflicted debate about 'compassionate conservation' (is compassion limited to animals?). I actually do believe individual nonhumans have moral standing; it is just that I see a community or ecosystem as having greater standing. I am Australian, and feral animals and invasive exotic plants have run amok here. In 2018 the Compassionate Conservation conference held here saw speakers defending feral cats and other invasive species, despite their huge impact on native species and ecosystems. For them the rights of individual introduced species overruled the rights of native species and ecosystems. I do not 
believe this is part of a 'just' ethics when the IPBES (2019) report notes that invasive species are among the five key causes of extinction.

7. The target article fails to foreground ecojustice and instead speaks of multi-species justice or expanding social justice to include nonhumans. I believe this is a serious mistake, as it fails to lobby for nonhuman nature in a clear term ('ecojustice'), treating it as an add-on to social justice (leaving justice for nature peripheral; Washington et al. 2018). This is not a 'fair balance' for the well-being of nonhumans.

8. The target article calls for trustees to be 'scientifically sophisticated'. But science is ethically dominated by (if not openly declared as upholding) anthropocentrism and neoliberalism (Washington 2018b). It is thus more important for trustees to be sophisticated in ecological ethics.

\section{References}

Cullinan, C. (2014). Governing people as members of the Earth community. In State of the World 2014: Governing for Sustainability. L. Mastny, ed. Washington: Island Press.

Curry, P. (2011). Ecological Ethics: An Introduction (Second Edition). Cambridge: Polity Press.

Gray, J. and Curry, P. (2019). Ecodemocracy and political representation for non-human nature. In Conservation: Integrating Social and Ecological Justice. H. Kopnina and H. Washington, eds. Washington: Springer.

IPBES. (2019). Nature's dangerous decline 'unprecedented'; Species extinction rates 'accelerating'. Media release by the Intergovernmental Science-Policy Platform on Biodiversity and Ecosystem Services.

Knudtson, P. and Suzuki, D. (1992). Wisdom of the Elders. Sydney: Allen and Unwin.

Kopnina, H. and Washington, H. (2019). Conservation: Integrating Social and Ecological Justice. Washington: Springer.

Rolston III, H. (2012). A New Environmental Ethics: The Next Millennium for Life on Earth. New York: Routledge.

Spash, C. (2012). New foundations for ecological economics. Ecological Economics 77, 36-47.

Treves, A., Santiago-Avila, F. and Lynn, W.S. (2018). Just preservation. Biological Conservation 229, 134-141.

Treves, A., Santiago-Avila, F. and Lynn, W.S. (2019). Just preservation. Animal Sentience 27(1). Washington, H. (2015). Demystifying Sustainability: Towards Real Solutions. London: Routledge. Washington, H. (2018a). The intrinsic value of geodiversity. The Ecological Citizen 1(2).

Washington, H. (2018b). A Sense of Wonder Towards Nature: Healing the World through Belonging. London: Routledge.

Washington, H. and Kopnina, H. (2019). Conclusion: A just world for life?. In Conservation: Integrating Social and Ecological Justice. H. Kopnina and H. Washington, eds. Washington: Springer.

Washington, H., Chapron, G., Kopnina, H., Curry, P., Gray, J. and Piccolo, J. (2018). Foregrounding ecojustice in conservation. Biological Conservation 228, 367-374.

Washington, H., Taylor, B., Kopnina, H., Cryer, P. and Piccolo, J. (2017). Why ecocentrism is the key pathway to sustainability. The Ecological Citizen 1, 35-41. 